\title{
The Acylamide Amidohydrolase of Candida utilis: Purification and Properties
}

\author{
By BERYL L. BRADY* \\ Laboratory of Microbiology, Gulbenkian Institute of Science, \\ Oeiras, Portugal
}

(Accepted for publication 22 July 1969)

\begin{abstract}
SUMM ARY
The amidohydrolase formed in the later stages of growth on glucose peptone medium by Candida utilis was purified 6o-fold from cell-free extracts. The purified enzyme hydrolysed mono- and di-carboxylic acid amides, benzamide, nicotinamide, pyrazinamide and certain $\beta$-hydroxyl substituted fatty acid amides, was inactive on L-asparagine and L-glutamine and was competitively inhibited by urea and $N$-methylurea. Acetamide and nicotinamide together showed mutual competition.
\end{abstract}

\section{INTRODUCTION}

Hydrolysis of aliphatic amides by micro-organisms has been reported as well as by liver and kidney tissue of rabbits (Bray, James, Thorpe \& Wasdell, 1950) and other animals. Bönicke (I962) used the capacity to hydrolyse a series of such amides to classify species of the genus Mycobacterium; Muftic (1963) and van Uden, VidalLeiria \& Buckley (I964) classified yeasts in a similar manner.

Gorr \& Wagner (1933) found that fresh and dried Candida utilis ('Torula utilis') hydrolised acetamide, propionamide and lactamide, whereas brewing and baking yeasts did not. Steiner (1959) extended to to the list of amides hydrolysed by dried C. utilis in buffer. An amidase from Pseudomonas fluorescens was purified 20-fold by Jakoby' \& Fredericks (1964), another from P. aeruginosa 35-fold by Kelly \& Kornberg (1964), and one from Mycobaterium smegmatis by Draper (1967) 2-2-fold.

Enzymes which hydrolyse nicotinamide have been reported more frequently: Hughes \& Williamson (I953) in cell-free extracts of Lactobacillus arabinosus; Pichappa \& Shanmugasundaram (1962) in a 40-fold purified preparation from Saccharomyces cerevisiae; Petrak, Greengard, Craston \& Sheppy (1965) in 38-fold purified material from rabbit and rat liver; Kirchner, Watson \& Chaykin (I966) in a 60-fold purified preparation from rabbit liver. Often the hydrolysis of other amides was not investigated. Others have had negative results with such hydrolyses: Oka (1954) in crude cell-free extracts of 'beer yeast' and Joshi \& Handler (I962) on an 850-fold purified nicotinamidase from Candida pseudotropicalis ('Torula cremoris').

Since Candida utilis gave promise of a capacity to hydrolyse a wide range of amides, it seemed worthwhile to purify the active material and to ascertain whether it consisted of one or more enzymes.

*Present address: Commonwealth Mycological Institute, Kew. 


\section{METHODS}

Organism. Candida utilis, IGC 3093, maintained in the culture collection of this laboratory.

Amide hydrolysis was tested as described by Jakoby \& Fredericks (1964). For routine tests during the course of purification, incubation was for I hr at $37^{\circ}$ with $0.0 \mathrm{I} \mathrm{M}$ -

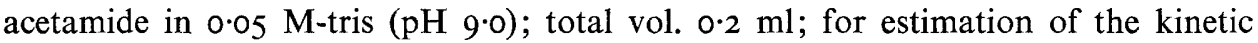
constants with various substrates, incubation was for $20 \mathrm{~min}$. and substrate concentrations appropriate to the affinity of the enzyme for the particular substrate were used. Ammonia was estimated by Nessler's reagent (Vanselow, 1940) in the range 0.04 to $0.38 \mu$ mole $\mathrm{NH}_{4}{ }^{+} / \mathrm{ml}$. One 'unit' is the amount of enzyme which catalyses the formation of I $\mu$ mole $\mathrm{NH}_{3} / \mathrm{min}$. $/ \mathrm{ml}$.

Compounds with a substituent on the amide nitrogen, since they do not form $\mathrm{NH}_{3}$ on hydrolysis, were examined as possible inhibitors of the hydrolysis of acetamide or of nicotinamide. The Michaelis-Menten constants and relative maximum velocities were obtained from double reciprocal plots (Lineweaver \& Burke, I934).

The low solubilities of some compounds limited their use in kinetic studies because enzyme affinities were generally low. Substances labile at $\mathrm{pH} 9.0$ were also assessed at low concentrations.

$\mathrm{N}$-acetyl- $\beta$-naphthylamine was tested as a substrate by the colorimetric method involving the formation of an azo dye (Goldbarg \& Rutenburg, 1958).

Glutamine hydrolysis was investigated at $\mathrm{pH} 7 \cdot 0$ and assayed by measuring any increase in glutamic acid over a control without added enzyme. After I hr at $25^{\circ}$, I ml. of enzyme + substrate mixture was passed through a column of Amberlite IRA-40I (acetate form) and six $\mathrm{I} \mathrm{ml}$. fractions were eluted with water followed by six I $\mathrm{ml}$. fractions eluted with $0.2 \mathrm{M}$-acetate buffer $(\mathrm{pH} 4.8)$. Glutamine and glutamate concentrations in the relevant eluate fractions were estimated with ninhydrin (Moore \& Stein, 1948).

Transferase activity was determined by the method of Brammar \& Clarke (I964) with incubation for $20 \mathrm{~min}$. at $37^{\circ}$. The extinction of the $\mathrm{FeCl}_{3}$-hydroxamate complex was read at $500 \mathrm{~nm}$. and compared with a standard curve prepared from acethydroxamate concentrations between 0.5 and $2.5 \mu \mathrm{mole} / \mathrm{ml}$. One 'unit' is the amount of enzyme catalysing the formation of I $\mu$ mole acethydroxamate $/ \mathrm{min} . / \mathrm{ml}$.

Protein was estimated by the method of Lowry, Rosebrough, Farr \& Randall (I95I) as modified by Eggstein \& Kreutz (I955), with bovine serum albumin as standard.

Preparation of cell-free extract. Candida utilis was grown for 5 days on a rotary shaker at $25^{\circ}$ in glucose $(2 \%, \mathrm{w} / \mathrm{v})$, peptone $(\mathrm{I} \%, \mathrm{w} / \mathrm{v})$, yeast extract $(0.5 \%, \mathrm{w} / \mathrm{v})$ medium. The organisms were washed twice with $0.02 \mathrm{M}-\mathrm{K}$ phosphate buffer $(\mathrm{pH} 6 \cdot 0)$, suspended in buffer ( $1 \mathrm{ml} . / \mathrm{g}$. wet wt) and shaken in $15 \mathrm{ml}$. batches with $50 \mathrm{~g}$. glass beads 0.45 to $0.50 \mathrm{~mm}$. diameter in a homogeniser (B. Braun, Melsungen, Model MSK) at $4000 \mathrm{cyc} . / \mathrm{min}$. for $2 \mathrm{~min}$., temperature between $\mathrm{I}^{\circ}$ and $10^{\circ}$. Ice-cold butanol was added slowly to the brei, with stirring, over $\mathrm{I} \mathrm{hr}$, to a final concentration of $3.8 \%$ $(\mathrm{v} / \mathrm{v})$, and stirring continued for a further $30 \mathrm{~min}$. After centrifugation at $\mathrm{1} 2,500 \mathrm{~g}$ for $\mathrm{I} \mathrm{hr}$ at $0^{\circ}$, the cell-free extract was dialysed overnight at $2^{\circ}$ against 50 vol. $0.0 \mathrm{I}$ $\mathrm{M}-\mathrm{K}$ phosphate buffer ( $\mathrm{pH} 6 \cdot 0$ ).

Enzyme fractionation. Partially purified enzyme was prepared from cell-free ex- 
tracts on four separate occasions, in the course of which the enzyme was purified between 28- and 80-fold. One such fractionation procedure is described below (and in Table I). On other occasions a fractionation by adding solid $\left(\mathrm{NH}_{4}\right)_{2} \mathrm{SO}_{4}$ in the presence of $10 \%(\mathrm{v} / \mathrm{v})$ ethanol was included, adsorption on calcium phosphate gel, and on one occasion a final fractionation on a column of DEAE-Sephadex.

Precipitation with protamine sulphate. Two successive precipitations with an aqueous solution of protamine sulphate, $20 \mathrm{mg}$. $/ \mathrm{ml}$., adjusted to $\mathrm{pH} 5.0$ with $\mathrm{NaOH}$, were made at $2^{\circ}$. The protamine sulphate was added with stirring during $15 \mathrm{~min}$. and stirring was continued for a further $30 \mathrm{~min}$. followed by centifugation at $7250 \mathrm{~g}$ for $20 \mathrm{~min}$. at $4^{\circ}$. Each addition was made on the basis of $\mu \mathrm{g}$. protamine sulphate $/ \mathrm{mg}$. protein in the cell-free extract before precipitation was started. The first to $85 \mu \mathrm{g} . / \mathrm{mg}$. protein, resulted in a heavy white precipitate which was discarded; secondly $35 \mu \mathrm{g}$. more protamine sulphate $/ \mathrm{mg}$. protein was added and produced a small translucent yellow precipitate which readily dissolved in $0.5 \mathrm{M}-\mathrm{K}_{2} \mathrm{HPO}_{4}$, giving a solution with about $12 \mathrm{mg}$. protein $/ \mathrm{ml}$. During subsequent dialysis overnight against two changes of $\mathrm{I} 60 \mathrm{vol}$. each of $0.03 \mathrm{M}$-tris $(\mathrm{pH} 8.0)$, at $4^{\circ}$, a heavy white precipitate appeared in the dialysis sac and was removed at $7000 \mathrm{~g}$ for $20 \mathrm{~min}$. at $4^{\circ}$. The supernatant fluid is referred to as protamine fraction in Table $\mathrm{I}$.

Table 1. Flow sheet of purification of acylamide amidohydolase of Candida utilis

\begin{tabular}{|c|c|c|c|c|c|c|c|c|}
\hline Extract & $\begin{array}{l}\text { Volume } \\
(\mathrm{ml} .)\end{array}$ & $\begin{array}{l}\text { Units/ } \\
\mathrm{ml} .\end{array}$ & $\begin{array}{l}\text { Total } \\
\text { Units }\end{array}$ & $\begin{array}{l}\text { Protein } \\
\mathrm{mg} / \mathrm{ml} \text {. }\end{array}$ & $\begin{array}{l}\text { Total } \\
\text { Protein } \\
\text { (mg.) }\end{array}$ & $\begin{array}{l}\text { Specific } \\
\text { Activity }\end{array}$ & $\begin{array}{l}\text { Yield } \\
(\%)\end{array}$ & $\begin{array}{l}\text { Purifi- } \\
\text { cation } \\
\text { (fold) }\end{array}$ \\
\hline $\begin{array}{l}\text { 3utanol-treated cell-free } \\
\text { extract }\end{array}$ & I96 & $6 \cdot 25$ & 1225 & 10.5 & 2058 & 0.59 & 100 & I \\
\hline Protamine fraction & $2 \mathrm{I}$ & $32 \cdot 19$ & 676 & $3 \cdot I$ & $65 \cdot I$ & 10.4 & 55 & $17 \cdot 6$ \\
\hline $\begin{array}{l}\text { Acetone precipitate } 2 \\
\text { dissolved } \\
\text { Sephadex fractions 9, Io, } \\
\text { I I pooled }\end{array}$ & $6 \cdot 4$ & $43 \cdot 4$ & 278 & 0.18 & 13.4 & $20 \cdot 7$ & $22 \cdot 7$ & $34 \cdot 8$ \\
\hline
\end{tabular}

Acetone precipitation. The protamine fraction was diluted with tris to give 25 units of activity $/ \mathrm{ml}$. and two successive precipitations with cold acetone were done: the first to $37 \cdot 5 \%(\mathrm{v} / \mathrm{v})$ acetone, the second to $64 \%(\mathrm{v} / \mathrm{v})$. Each precipitate was removed by centrifugation at $7000 \mathrm{~g}$ for $30 \mathrm{~min}$.; the first was discarded and the second was

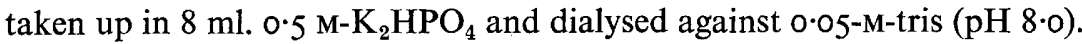

Column chromatography on Sephadex G200. A column of Sephadex G 200, $4.9 \mathrm{~cm}^{2}$ $\times 3 \mathrm{I} \mathrm{cm}$., equilibrated with $0.05 \mathrm{M}$-tris $(\mathrm{pH} \mathrm{8} \cdot 0)$ containing $0.05 \mathrm{M}-\mathrm{NaCl}$, was charged with the $6.4 \mathrm{ml}$. sample containing $13.4 \mathrm{mg}$. protein. The flow of tris $+\mathrm{NaCl}$ solution was maintained by gravity at a rate of $15 \mathrm{ml} . / \mathrm{hr} ; 5 \mathrm{ml}$. fractions were collected. The protein eluted from the column appeared as a single peak in a volume of $50 \mathrm{ml}$. after $30 \mathrm{ml}$. had passed through the column, and was coincident with the single peak of enzyme activity. The three most active fractions were combined and had a specific activity of 36 , giving a 60 -fold purification with a yield of $8.5 \%$. This material retained its activity over 8 months at $4^{\circ}$.

Chemicals. All chemicals were of analytical grade wherever possible; most were commercial products. Nicotinamide was twice recrystallised from benzene. $N$-acetylnaphthylamine was prepared by Professor Bernado Herold of the Instituto Superior 
Técnico, Lisbon; oxytetracycline $\mathrm{HCl}$ and tetracycline $\mathrm{HCl}$ were gifts from Chas. Pfizer and Co. and the remaining tetracycline compounds from Lederle Laboratories.

Buffers. All buffers and solutions of substrates contained 0.5 mM-ethylenediaminetetraacetic acid (EDTA).

\section{RESULTS}

Evidence that a single amidase is active on a wide range of substrates

Substrate specificity throughout the purification process. Whole cells of Candida utilis are able to hydrolyse a wide range of compounds containing amide groups. Cellfree extracts and the 6o-fold purified material hydrolysed the amides listed in Table 2, with the exception of asparagine, which was hydrolysed by crude cell-free extracts but not by the purified enzyme, and isonicotinamide, which was weakly hydrolysed by the purified enzyme and not detectably by the cell-free extract.

Table 2. Hydrolysis (as \% of activity with acetamide) of various substrates by cell-free extract of Candida utilis and purified enzyme preparation

$\begin{array}{lcc}\text { Amide (80 MM) } & \text { Cell-free extract } & \begin{array}{c}\text { 60-fold purified } \\ \text { preparation }\end{array} \\ \text { Acetamide } & \text { I00 } & \text { I00 } \\ \text { N-Valeramide } & 90 & 59 \\ \text { Propionamide } & 82 & 59 \\ \text { N-Hexoamide } & 80 & 66 \\ \text { Pyrazinamide } & 78 & 27 \\ \text { Acrylamide } & 43 & 46 \\ \text { N-Butyramide } & 40 & 33 \\ \text { Nicotinamide } & 16 & 13 \\ \text { Malonamide } & 15 & 22 \\ \text { Asparagine } & 13 & 0 \\ \text { Isonicotinamide } & 0 & 4.5\end{array}$

During the course of several purifications the activity of the material was assayed by using as substrate Io mM-acetamide or nicotinamide. The activity with nicotinamide was between 9 and $12 \%$ of that with acetamide in the cell-free extract both before and after treatment with butanol, and in the supernatant fluid after the first precipitation with protamine sulphate. However, after the second precipitation with protamine sulphate, and throughout the subsequent purification, the activity on nicotinamide diminished to between 3 and $6 \%$ of that on acetamide.

In one of the later purification experiments, when the Michaelis-Menten constant for nicotinamide of the purified enzyme had been found to lie between 5 and 10 $\times 10^{-2} \mathrm{M}$, the nicotinamidase activity of the second protamine sulphate supernatant fluid indicated that there was material present with a much higher affinity for nicotinamide, of $K_{m}$ between I and $4 \times \mathrm{IO}^{-3} \mathrm{M}$. Elimination of this activity with the supernatant fluid accounts for the decrease in the ratio of nicotinamide:acetamide hydrolysis.

Simultaneous hydrolysis of acetamide and nicotinamide by the 6o-fold purified material. Acetamide was taken as a typical representative of the range of simple aliphatic amides hydrolysed by the Candida utilis enzyme, and nicotinamide as a substrate more commonly hydrolysed by cells in general. Initial velocities were determined for three concentrations of acetamide and one concentration of nicotinamide, separately and mixed. 
The velocities of hydrolysis in the mixed assays were lower than the sums of the velocities of the separate assays. The observed velocities of the mixed assays agreed well with calculated values based on competition of two substrates for one active site on the same enzyme (Table 3 ). The kinetic parameters used in the calculations were obtained from Lineweaver-Burk plots.

Table 3. Hydrolysis of acetamide and nicotinamide, separately and together by the 6o-fold purified enzyme preparation from Candida utilis

\begin{tabular}{|c|c|c|c|c|c|}
\hline $\begin{array}{l}\text { Substrate c } \\
\text { Acetamide } \\
\text { (M) }\end{array}$ & $\begin{array}{l}\text { (b) Nicotinamide } \\
\text { (M) }\end{array}$ & $\begin{array}{c}\text { Velocities } \\
\text { with separate } \\
\text { substrates }\end{array}$ & $\begin{array}{c}\text { Sum of } \\
\text { velocities } \\
\text { with separate } \\
\text { substrates }\end{array}$ & $\begin{array}{l}\text { Velocities } \\
\text { with mixed } \\
\text { substrates } \\
v_{\text {obs }}\end{array}$ & $\begin{array}{c}\text { Calculated } \\
v_{1}+v_{2} \\
\text { in mixed } \\
\text { substrates* }\end{array}$ \\
\hline \multicolumn{6}{|c|}{$\mu$ mole $\mathrm{NH}_{3} / \mathrm{ml} . / 20 \mathrm{~min}}$. \\
\hline $10^{-3}$ & - & 0.675 & 2.4 & $2 \cdot I$ & \\
\hline - & $2 \times 10^{-1}$ & $I \cdot 725$ & 2.4 & $2 \cdot 1$ & 23 \\
\hline $2 \times 10^{-3}$ & $2 \overline{\times} 10^{-1}$ & $\begin{array}{l}I \cdot 380 \\
I \cdot 725\end{array}$ & $3 \cdot 105$ & $2 \cdot 385$ & $2 \cdot 75$ \\
\hline${\frac{10^{-8}}{-}}^{-8}$ & $2 \overline{\times} 10^{-1}$ & $\begin{array}{l}5 \cdot 355 \\
I \cdot 725\end{array}$ & $7 \cdot 08$ & $4 \cdot 605$ & $4 \cdot 88$ \\
\hline \multicolumn{6}{|c|}{$V_{a} a K_{b}+V_{b} b K_{a}$} \\
\hline
\end{tabular}

where $V_{a}$ and $V_{b}$ are maximum velocities and $K_{a}$ and $K_{b}$ Michaelis constants.

Competitive inhibition by urea and $N$-methylurea. Urea was a competitive inhibitor of hydrolysis of acetamide and of nicotinamide by the 60-fold purified enzyme preparation. By using three different concentrations of inhibitor in each case, the inhibition constant, $K_{i}$, for urea was calculated. The average $K_{i}$ urea obtained with acetamide $\left(\mathrm{II} \times 1 \mathrm{IO}^{-3} \mathrm{M}\right)$ agreed well with the average with nicotinamide $\left(8.4 \times 10^{-3} \mathrm{M}\right)$.

$\mathrm{N}$-methylurea was a competitive inhibitor with even higher affinity for the enzyme. The average $K_{i}$ of $\mathrm{N}$-methylurea with acetamide was $7 \cdot 5 \times 1 \mathrm{I}^{-4} \mathrm{M}$ and with nicotinamide, $6.5 \times 10^{-4} \mathrm{M}$. These results are additional evidence that only one enzyme was involved in the hydrolysis of both substrates.

\section{Properties of the enzyme}

Optimum $\mathrm{pH}$ value for amide hydrolysis. With $80 \mathrm{~mm}$-acetamide in $0.05 \mathrm{M}$-phosphate buffer over a range $\mathrm{pH} 6.0$ to $7 \cdot 9$, and in $0.05 \mathrm{M}$-tris $+\mathrm{HCl}$ buffer over a range $\mathrm{pH}$ 6.7 to $9 \cdot 8$, the optimum $\mathrm{pH}$ was $9 \cdot 0$. Within the region where both buffer systems operate, activity in phosphate buffer was approx. $15 \%$ higher than activity in tris at the same $\mathrm{pH}$ value. With $80 \mathrm{~mm}$-acetamide $\left(\mathrm{pH}^{\circ}{ }^{\circ}\right)$ activity was linear over a period of I hr.

Substrate specificity and competitive inhibitors. The range of enzyme activity with respect to a number of compounds containing a free or substituted amide group is shown in Table 4. Straight-chain aliphatic monoamides with 2 to 6 carbon atoms had Michaelis-Menten constants of similar orders of magnitude, between 2 and 5 $\times \mathrm{IO}^{-3} \mathrm{M}$ and relative maximum velocities between 28 and $100 \%$ of $V_{\max }$ of acetamide. Nicotinamide had an affinity for the enzyme approximately to times lower than had the series of aliphatic amides, while the relative maximum velocity of hydrolysis of nicotinamide lay within the same range as for the latter group. 
Of the substrates tested as inhibitors, only urea and N-methylurea showed an effect, both being competitive inhibitors. Among the compounds tested several, such as NAD and carbamylphosphate, are physiologically active, while 4-amino-5-imidazole carboxamide is encountered in purine biosynthesis as the ribotide. Also tested were antibiotics of the tetracycline series containing an amide group, and certain nicotinamide analogues either found in nature or of pharmaceutical use. None showed activity either as substrate or inhibitor. However, several such compounds activated acetamide and nicotinamide hydrolysis. This group included products of the amidase reaction (acetate and nicotinate) and certain structural analogues of nicotinamide such as picolinate, quinolinate and $\mathrm{N}_{1}$ methylnicotinamide.

Table 4. Specificity of the 6o-fold purified acylamide amideohydrolase from Candida utilis

Compounds

Acetamide

Propionamide

n-Butyramide

Isobutyramide

$n$-Valeramide

$n$-Hexamide

Acrylamide

Malonamide

Succinamide

Adipamide

Benzamide

Nicotinamide

Isonicotinamide

(pyridine-4-carboxamide)

Pyrazinamide

Glycolamide

DL-Lactamide

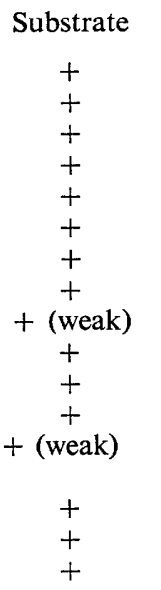

$V_{\max }{ }^{*}$
100
63
28
-
88
88
42
6
-
-
-
32
-
18
36
65

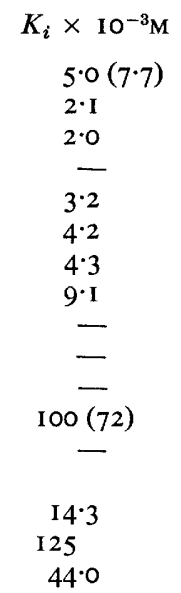

Inhibitors (competitive): Urea $\left(K_{i}\right.$ I I $\times 10^{-3} \mathrm{M}$ with acetamide as substrate). $N$-methylurea $\left(K_{i}\right.$ $0.75 \times 10^{-3} \mathrm{M}$ with acetamide as substrate).

Activators: $N_{1}$-methylnicotinamide $\left(8 \times 10^{-3} \mathrm{M}\right.$ approx. doubles $V_{\max }$ acetamide); picolinate, nicotinate, quinolinate, acetate $\left(200 \times 10^{-3} \mathrm{M}\right.$ approx. doubles $V_{\max }$ acetamide).

Compounds not affected by the amidase: Formamide, oxamide, salicylamide, L-asparagine, Lglutamine, $N$-methylacetamide, $N$-phenylacetamide, $p$-acetamidophenol, $N$-acetylglycine, $N$-acetylDL-methionine, $N$-acetyl- $\beta$-D-glucosamine, $N$-acetyl- $\beta$-naphthylamine, allantoin, NAD, 4 -amino-5imidazole carboxamide $\mathrm{HCl}$, carbamylaspartic acid, carbamylphosphate, 7-chloro-6-dimethyltetracycline $\mathrm{HCl}$, chlorotetracycline $\mathrm{HCl}$, 6-dimethyl-tetracycline AIX base, oxytetracycline $\mathrm{HCl}$, tetracycline $\mathrm{HCl}$.

* \% of activity with acetamide as substrate.

Transferase activity. The 6o-fold purified enzyme catalysed the transfer of the acyl group of acetamide to hydroxylamine. At $\mathrm{pH} 7 \cdot 2$ the number of units $/ \mathrm{ml}$. was II 4 compared with 6.5 units of hydrolase activity at $\mathrm{pH} 99^{\circ}$. . Later, the optimum for transferase activity was found to be near $\mathrm{pH} 8$, but the high blank values for the $\mathrm{FeCl}_{3}$ mixture at alkaline $\mathrm{pH}$ values made precise evaluation difficult. No further study was made of the transferase activity of either the crude cell-free extracts or of the purified material. 
DISCUSSION

The enzyme purified by Kelly \& Kornberg (1964) from Pseudomonas aeruginosa catalysed the hydrolysis of aliphatic amides and the transfer of the acyl moiety of the amides or of the corresponding acids to hydroxylamine. McFarlane, Brammar \& Clarke (1965) showed the same enzyme to be active on esters, though with a limited specificity and a low affinity for the substrates. According to Kelly \& Kornberg, amidase activity is but one instance of acyl transfer from a suitable donor through an intermediate acyl protein to an acceptor of the type $\mathrm{X}-\mathrm{OH}$ where $\mathrm{X}$ may be $\mathrm{H}$ or $\mathrm{NH}_{2}$, and the enzymes should be more properly called acyl transferases rather than hydrolases. However, work with organisms of the genus Mycobacterium has shown (Kimura, 1959; Draper, 1967) that while in some species the amidase and transferase activities are intimately related and apparently properties of the same enzyme, in others they can be readily separated. Although the transferase activity of the Candida utilis enzyme was examined only with respect to acetamide as substrate, it was present to a marked extent in the 6o-fold purified material and is probably characteristic of the enzyme.

The range of substrates hydrolysed by the Candida utilis amidase confirms and extends that cited by Steiner (1959) for dried organisms of the same species in buffer. In comparison with enzymes isolated from other organisms, the purified $C$. utilis enzyme had a wider substrate specificity than that from Pseudomonas aeruginosa (Kelly \& Kornberg, I964; Brown, Brown \& Clarke, 1969) although both enzymes were similar in having no affinity for compounds with a substitution on the amide nitrogen and both retained the ability to transfer the acyl moiety of acetamide to hydroxamate. The wide substrate range of the $C$. utilis enzyme approaches that of the amidase from Mycobacterium smegmatis (Draper, 1967) which also was unable to hydrolyse $\mathrm{N}$-substituted amides. The affinity of the $C$. utilis amidase for acetamide was within the same order of magnitude as that of the $P$. fluorescens enzyme (Jakoby \& Fredericks, 1964), whereas for propionamide it was higher.

Inhibition by urea and $\mathrm{N}$-methylurea of the Candida utilis enzyme, which was competitive, contrasts with non-competitive inhibition in the enzymes from Pseudomonas spp. (Kelly \& Kornberg, 1964; Jakoby \& Fredericks, 1964).

The low affinity for nicotinamide of the Candida utilis amidase contrasts with the usually higher affinity of enzymes which appear to function primarily in the conversion of nicotinamide to nicotinate in the metabolism of NAD and which appear not to be active on simple aliphatic amides. It seems possible that the nicotinamidase activity detected in the second supernatant fluid of the protamine sulphate precipitation of the $C$. utilis preparation $\left(K_{m} \mathrm{I}\right.$ to $\left.4 \times 10^{-3} \mathrm{M}\right)$ indicates an enzyme of the latter type.

The function of the acyl amidase of Candida utilis remains obscure. In glucose yeast-extract peptone medium amidase activity develops after the logarithmic phase of growth, when the glucose supply has been exhausted; in a similar medium without glucose it is formed without preliminary repression (Brady \& van Uden, I966). Brammar \& Clarke (I964) showed the Pseudomonas aeruginosa amidase to be subject to catabolite repression. In exponentially growing cultures on succinate medium this pseudomonad enzyme was inducible by substrate and by certain non-substrate analogues of acetamide. It is not known whether the Candida utilis enzyme might be inducible under favourable conditions since all experiments to test substrates as in- 
ducers were made in the presence of glucose. A search for possible natural substrates for the acyl amidase showed no activity with NAD, the 4-amino-5-imidazole carboxamide moiety of the corresponding ribotide, carbamylaspartic acid, carbamylphosphate or various tetracyclines. Despite the fact that the enzyme is active on dicarboxylic acid amides derived from aromatic and heterocyclic compounds, e.g. benzamide and nicotinamide, it seems appropriate to name it according to the substrates on which it is most active, namely as an acylamide amidohydrolase EC 3.5.I.4.

This work was supported by a fellowship awarded by the United Kingdom Branch of the Calouste Gulbenkian Foundation, Lisbon. The author wishes to thank Dr N. van Uden, Director of the Laboratory of Microbiology, Gulbenkian Institute of Science, for suggesting the subject of investigation and for his continued encouragement and lic. biol. Maria-Cecília Cabeça Silva for her valuable technical assistance.

\section{REFERENCES}

BöNICKE, R. (1962). L'identification des mycobactéries à l'aide de méthodes biochimiques. Bull. Un. int. Tuberc. 32, 13.

BRADY, B. L. \& VAN UdEN, N. (I966). Effects of growth conditions on development of amidase activity in Candida utilis. Proc. 2nd Int. Symp. on Yeasts, Bratislava, I966, p. 497.

Brammar, W. J. \& Clarke, P. H. (1964). Induction and repression of Pseudomonas aeruginsa amidase. J. gen. Microbiol. 37, 307.

Bray, H. G., James, S. P., Thorpe, W. V. \& Wasdell, M. R. (1950). The fate of certain organic acids and amides in the rabbit. II. Further observations on the hydrolysis of amides by tissue extracts. Biochem. J. 47, 294.

Brown, J. E., Brown, P. R. \& Clarke, P. H. (I969). Butyramide-utilizing mutants of Pseudomonas aeruginosa 8602 which produce an amidase with altered substrate specificity. J. gen. Microbiol. $57,273$.

DrAPER, P. (1967). The aliphatic acylamide amidohydrolase of Mycobacterium smegmatis; its inducible nature and relation to acyl-transfer to hydroxylamine. J. gen. Microbiol. 46, II I.

EgGstein, M. \& KReUTZ, F. H. (1955). Vergleichende Untersuchungen zur quantitativen Eiweissbestimmung in Liqour und eiweissarmen Lösungen. Klin. Wschr. 33, 879.

GoldbarG, J. A. \& RutenburG, A. M. (1958). The colorimetric determination of leucine aminopeptidase in urine and serum of normal subjects and patients with cancer and other diseases. Cancer N.Y. II, 283.

GoRR, G. \& WAGNER, J. (1933). Über das Amidspaltungsvermögen der Torula utilis. Biochem. $Z$. 266, 96.

Hughes, D. E. \& Williamson, D. H. (I953). The deamidation of nicotinamide by bacteria. Biochem. $J .55,85$ I.

JAKOBY, W. B. \& Fredericks, J. (I964). Reactions catalysed by amidases. Acetamidase. J. biol. Chem. 239, 1978.

Joshi, J. G. \& Handler, P. (1962). Purification and properties of nicotinamidase from Torula cremoris. J. biol. Chem. $237,929$.

Kelly, M. \& KorNBerg, H. L. (1964). Purification and properties of acyltransferases from Pseudomonas aeruginosa. Biochem. J. 93, 557.

KIMURA, T. (1959). Studies on metabolism of amides in Mycobacteriaceae. III. Amidases and transferases in extracts from Mycobacteriaceae. J. Biochem., Tokyo 46, I 27 I.

KirchneR, J., WATSON, J. G. \& ChaYkin, S. (1966). Nicotinamide deamidase from rabbit liver. $J$. biol. Chem. 24I, 953.

Lineweaver, H. \& BURKe, D. (1934). The determination of enzyme dissociation constants. J. Am. chem. Soc. 56, 658.

Lowry, O. H., Rosebrough, N. J., Farr, A. L. \& Randall, R. J. (I95I). Protein measurement with the Folin phenol reagent. J. biol. Chem. 193, 265. 
MCFarlane, N. D., Brammar, W. J. \& Clarke, P. H. (I965). Esterase activity of Pseudomonas aeruginosa amidase. Biochem. J. 95, 24c.

Moore, S. \& STEIN, W. H. (1948). Photometric ninhydrin method for use in the chromatography of amino acids. $J$. biol. Chem. $176,367$.

Muftic, M. K. (1963). Die Klassifizierung der verschiedenen Arten der Gattung Candida mit der 'Amid-Reihe' nach Bönicke. In Hefepilze als Krankheitserreger bei Mensch und Tier 9. BerlinGöttingen-Heidelberg: Springer-Verlag.

OKA, Y. (I954). Studies on hydrolytic enzyme of nicotinamide. I. Nicotinamidase of beer yeast. $J$. Biochem., Tokyo 4I, 89.

Petrak, B., Greengard, P., Craston, A. \& Sheppy, F. (1965). Nicotinamide deamidase from mammalian liver. J. biol. Chem. 240, I725.

Pichappa, C. V. \& Shanmugasundaram, E. R. B. (1962). Studies on nicotinamide deamidase of Saccharomyces cerevisiae. Proc. natn. Inst. Sci. India B 28, 432.

STEINER, M. (I959). The utilization of amino and amide nitrogen by Endomycopsis vernalis and other yeasts (with special reference to metabolic reactions at the surface of the cells). Symp. Soc. exp. Biol. $\mathbf{1 3}, \mathbf{1 7 7 .}$

Uden, N. VAN, Vidal-Leiria, M. \& Buckley, H. R. (I964). Utilization of nitrogen compounds by Cryptococcus neoformans and other yeasts. Annls. Soc. belge Méd. trop. 44, 619.

VANSELOW, A. P. (1940). Preparation of Nessler's reagent. Ind. Engng Chem. analyt. Edn. I2, 5 I 6. 